\title{
Formulation of Resveratrol Nanoemulsion by Phase Inversion Technique and Evaluation of Anti-Cancer Activity on Human Colon Cancer Cell Lines
}

\author{
Sabna Kotta \\ Department of Pharmaceutics, Faculty of Pharmacy, King Abdulaziz University, Jeddah, SAUDI ARABIA.
}

\begin{abstract}
Colorectal cancer is in third place among the most usually detected cancer worldwide. Many natural compounds have been proved for its efficacy in the treatment of different types of carcinomas. Resveratrol a polyphenolic phytoalexin found in several sources including grapes, berries, etc. Like most of the polyphenols resveratrol also exhibits poor aqueous solubility and hence bioavailability. In this study nanoemulsion of resveratrol has been formulated using a low energy technique (phase inversion composition) using capryol as oil phase. The optimized formulations were evaluated for size of nanodroplets, zeta potential as well as in vitro drug release. The resveratrol nanoemulsion was evaluated on HCT-166 cell lines to study the inhibitory effect on the viability of human colorectal cancer cell and compared with resveratrol suspension and blank nanoemulsions. Transmission electron microscopy and dynamic light scattering revealed the globule size of nanoemulsion was $113.6 \pm 18.21 \mathrm{~nm}$ with a zetapotential of $-15.12 \pm 1.028$. In vitro release profile showed above $80 \%$ release within $6 \mathrm{hr}$. The results of the cell line studies showed that the developed resveratrol nanoemulsion was cytotoxic to the colon cancer cells while non-toxic to the non-tumor cells. Hence, the developed resveratrol nanoemulsion was proved to be a promising approach for colon cancer management.
\end{abstract}

Key words: Resveratrol, Lung cancer, HCT-166 cells, Nanoemulsion, Phytochemicals.

\section{INTRODUCTION}

Lung, colorectal and breast cancer are the most frequent lethal types of cancers worldwide. As per cancer statistics 2020, colorectal carcinoma is the second most significant cause of death related to cancer in United States. ${ }^{1-4}$ Current chemotherapy methods for treating cancers are associated with major toxicities. Therefore, naturally occurring plant products, which are nontoxic are favored as compared to synthetic agents. Resveratrol is such naturally occurring dietary compound, which proved to be a potential compound for the treatment of colon cancer. Resveratrol is a polyphenolic compound mainly found in grape skin berries etc. function as a chemotherapeutic agent against colorectal carcinomas and many other types of cancers. Resveratrol chemically 3,4',5-trihydroxy-trans-stilbene occur in high levels in grape skin up to $100 \mu \mathrm{g} / \mathrm{g}$ and in red wine up to $20 \mathrm{mg} / \mathrm{L}$.

It possesses wide-ranging biological properties including cardioprotective, anti-platelet aggregation, immunomodulatory as well as neuroprotective actions. The discovery of anti-cancer effect of resveratrol in colon cancer as well as other carcinomas aroused a great enthusiasm in grapes and related dietary supplements. This polyphenol has proved its efficacy in the management of cancer in different stages of carcinogenesis due to its capability to arrest cell-cycle and triggering of apoptosis. ${ }^{5-9}$ Many studies have found that resveratrol could induce tumor cell apoptosis by mitochondrial dependent pathways which that partly depended on Bax conformational changes as well as cellular redistribution. ${ }^{10,11}$ Some studies
Submission Date: 06-05-2021; Revision Date: 10-07-2021; Accepted Date: 26-08-2021

DOI: 10.5530/ijper.55.3s.168 Correspondence: Dr. Sabna Kotta, Assistant Professor, Department of Pharmaceutics, Faculty of Pharmacy, King Abdulaziz University, Jeddah-21589, SAUDI ARABIA.

Phone: 00966558734418 , Email: skotta@kau.edu.sa

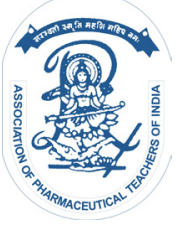

www.ijper.org 
have proved that Fas-mediated pathways can contribute to killing of cells which are subjected to different stimulus like anti-cancer agents and immune modulatory molecule in a ligand-dependent or -independent manner. ${ }^{10,12}$

Like most of the polyphenols, resveratrol belong to the class-2 of the BCS (Biopharmaceutics Classification System) hence exhibits poor aqueous solubility and bioavailability. ${ }^{13}$ There are extensive researches are going on to augment the solubility and hence the bioavailability of this natural compound for maximizing its therapeutic potential. The nanotechnology related formulation development strategies seems to be efficient in enhancing the bioavailability. Nanotechnology utilized carriers have been highly researched in-vitro and also in-vivo to discover the impacts on bioavailability as well as efficacy. Which include nanosuspensions, ${ }^{14}$ polymeris nanoparticles, ${ }^{15-17}$ polymeric hydrogels, ${ }^{18}$ selfnanoemulsifying drug delivery systems, ${ }^{15,19}$ liposomes, ${ }^{20}$ solid lipid nanocarriers, ${ }^{21}$ protein based nanocarriers ${ }^{22}$ and cyclodextrin complexes. ${ }^{23}$ Among these approaches the most prevalent one is the encapsulation or incorporation of the drug into inactive lipid carrier like oil, surfactant dispersions, micro/nanoemulsions etc. Amongst these nanoemulsions can enhance the bioavailability by improving the solubility of lipophilic bioactive very efficiently..$^{24,25}$ Nanoemulsions have generally droplet size less than $200 \mathrm{~nm}$ and are stable isotropic systems of two immiscible liquid phases formulated with the help of surfactants. ${ }^{26,27}$

In the present study a nanoemulsion of resveratrol is formulated by a phase inversion technique which does not require high energy for the preparation. After characterization, the nanoemulsion is evaluated on HCT -166 human colon cancer cell lines for cell viability assay and the result was compared with blank nanoemulsion and resveratrol suspension. To the best of our understanding no research has been published on resveratrol nanoemulsion to prove the anticancer action on human colon cancer cell line.

\section{MATERIALS AND METHODS}

Resveratrol, capryol 90, olive oil, labrafil, tween 20, tween 80, triacetin, PEG 400, span 20, ethanol and propylene glycol were obtained from Sigma (Sigma Aldrich-Germany). All chemicals used were of analytical grade and commercially available.

\section{Selection of oil, surfactant and co-surfactant}

Determination of solubility of drug in different components of nanoemulsion is important to ensure maximum solubility and stability. To assess the solubility of resveratrol, extra amount of drug incorporated in fixed amount of different oils and surfactants and mixed by vortex shaker for $5 \mathrm{~min}$ and then kept in a shaking water bath (GFL- Burgwedel, Germany) for 72 $\mathrm{h}\left(37^{\circ} \mathrm{C}\right)$. The solutions were centrifuged using a laboratory centrifuge (NF 800R NUVE, Turkey) for $30 \mathrm{~min}$ $(5000 \mathrm{rpm})$. The upper portion were taken and methanol was added to dilute the sample and amount of resveratrol solubilized was determined at $306 \mathrm{~nm}$ using UV-Visible spectrophotometer.

\section{Preparation of nanoemulsion}

Nanoemulsion weas prepared by using phase inversion composition method. First resveratrol was solubilized in Capryol 90. Then surfactant (Tween 20) and cosurfactant (PEG 400) were mixed to form Smix and different quantities of this mixture was added to fixed amount of oil and mixed well with vortex shaker. Then water was added slowly and mixed continuously using vortex mixer. ${ }^{28-30}$

\section{Characterization of optimized nanoemulsion Droplet size and PDI}

Zetasizer Nano was used to establish the droplet size of nanoemulsion (Malvern Instruments LimitedWorcestershire, UK). Dynamic light scattering technique was the principle behind. Nanoemulsion was diluted 100 times before experiment so as to prevent multiple scattering effects. All the measurements were done in triplicate.

\section{Zeta potential}

Zeta potential of the formulations was measured by Zetasizer Nano (Malvern Instruments Limited, Worcestershire, UK). The surface charge was calculated as an average of three readings.

\section{Transmission electron microscopy (TEM)}

The morphology of resveratrol nanoemulsion formulation was illustrated by TEM as per previous published methods. ${ }^{22} \mathrm{~A}$ drop of the nanoemulsion sample after suitable dilution was placed directly on copper grid. Before analysis, the staining was done for $30 \mathrm{sec}$ with phosphotungstic acid (2\%) and finally air dried.

\section{In vitro drug release}

Amount of resveratrol released from the developed nanoemulsion was compared with a resveratrol suspension. Suspension of resveratrol was formulated by suspending resveratrol in $1 \%$ sodium carboxy methyl cellulose in water. The final concentration of resveratrol in suspension was $8 \mathrm{mg} / \mathrm{ml}$. Drug release 
from developed resveratrol nanoemulsion and suspension were determined. Formulations were filled in the cellulose membrane tubing (molecular cut off $12000 \mathrm{Da}$, Sigma -Aldrich, USA) with the help of a clip. The filled bags were tied on the paddles of USP dissolution apparatus type $2.900 \mathrm{ml}$ of $\mathrm{pH} 6.8$ phosphate buffer used as dissolution medium and instrument was operated at $50 \mathrm{rpm}$. Samples were withdrawn $(5 \mathrm{ml})$ at $0,0.5,1,2,4,6$, and $8 \mathrm{~h}$ for measuring the drug release and same amount of fresh medium was returned to recompense the volume loss. Resveratrol content was measured from the samples at $306 \mathrm{mn}$ in a UV-Visible spectrophotometer (UV-2600 Shimadzu). The drug released from the nanoemulsion was compared with resveratrol suspension.

\section{Cell culture}

HCT166 (human colorectal cancer cell line) cells were obtained from the American Type Culture Collection (ATCC). HCT166 cells were cultured in DMEM (Dulbecco's modified Eagle's medium) and supplemented with FBS (fetal bovine serum 10\%), 100 I.U/mL of penicillin, and $100 \mu \mathrm{g} / \mathrm{mL}$ streptomycin. All these reagents were purchased from Sigma -Aldrich, USA. The cells were grown in a humidified incubator in $5 \%$ $\mathrm{CO}_{2}$ at $37^{\circ} \mathrm{C}$.

\section{In-vitro cytotoxicity analysis}

The anticancer property of resveratrol nanoemulsion was studied using a previously described method. To determine the toxicity of optimized formulation and suspension toward cultured cells MTT assay was used. 96-well plates were used to seed the cells and allowed to grow confluence of 70 to $80 \%$. The HCT166 cells were added with various concentrations $(20,30,40 \mu \mathrm{M})$ of formulations for $24 \mathrm{hr}$ with DMSO. After removing the media, $10 \mu \mathrm{l}$ of sterile and filtered 3-(4,5-dimethylthiazol-2-yl) -2,5-diphenyltetrazolium bromide (MTT) in phosphate buffered saline $(5 \mathrm{mg} / \mathrm{mL})$ was put in to each well to have a final concentration of $0.4 \mathrm{mg} / \mathrm{mL}$. After $3 \mathrm{~h}$ of re-incubation of the plates for allowing the metabolism of MTT by viable cells to form insoluble formazan crystals, the media and unconverted MTT were aspirated. Then $150 \mu \mathrm{l}$ of DMSO was put in to each well for ensuring complete solubilization of formazan. The absorbance were noted on a BioTek Synergy $\mathrm{H} 1$ microplate reader at $490 \mathrm{~nm} .^{31,32}$ The formula given below was used to calculate percentage of inhibition.

$\%$ Cell viability $=($ Mean absorbance of control - Mean absorbance of treated cells)/ Mean absorbance of control $\times 100$

\section{Cell Morphological Analysis}

Resveratrol nanoemulsion (F), blank nanoemulsion (B) and resveratrol suspension (S) at different concentrations $(20,30,40 \mu \mathrm{M})$ tested on HCT166 cells (seeding density $2.5 \times 10^{3}$ cells/well) in 24-well plates. Treated as well as untreated cells were then cultured in $5 \% \mathrm{CO}_{2}\left(37^{\circ} \mathrm{C}\right)$ in an incubator for $24 \mathrm{hr}$. Microscopic images were captured after experimental procedure to analyze any visible changes in cell morphology.

\section{Statistical Analysis}

The mean \pm standard deviation of three replicates for individual assays are presented in data. SPSS 22.0 software was used determine the statistical significance. $* p<0.05, * * p<0.01$, and $* * * x<0.001$ indicates statistical significance in comparison with the untreated control cells.

\section{RESULTS AND DISCUSSION}

\section{Formulation of resveratrol nanoemulsion}

Nanoemulsions were formulated by a low energy technique using phase inversion composition technique. The free energy required to form nanoemulsion is highly dependent on the extent to which the surfactant reduces or lessens the surface tension between oil and water interface. It also depends on the changes in dispersion entropy. Hence a negative free energy of formation is accomplished when great decrease in the surface tension is supplemented by major beneficial entropic change. Therefore in these conditions the process of nanoemulsification will be spontaneous and the resultant dispersion will be stable. ${ }^{29}$ Based on the solubility and miscibility study capryol 90 was selected as oil, tween 20 as surfactant and PEG 400 as cosurfactant (Figure 1). Different trials have been done with varying ratios oil and surfactant. Different ratios of Tween 20 and PEG400 also tried (Table 1). Formula-

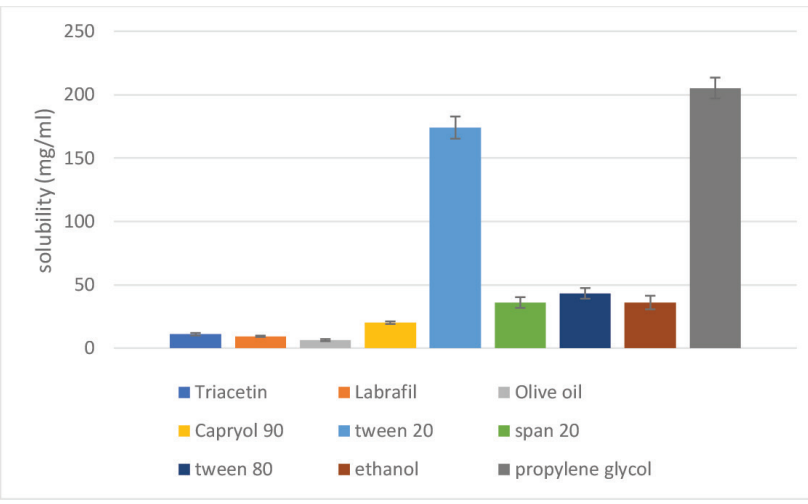

Figure 1: Resveratrol solubility in different oils and surfactants. 


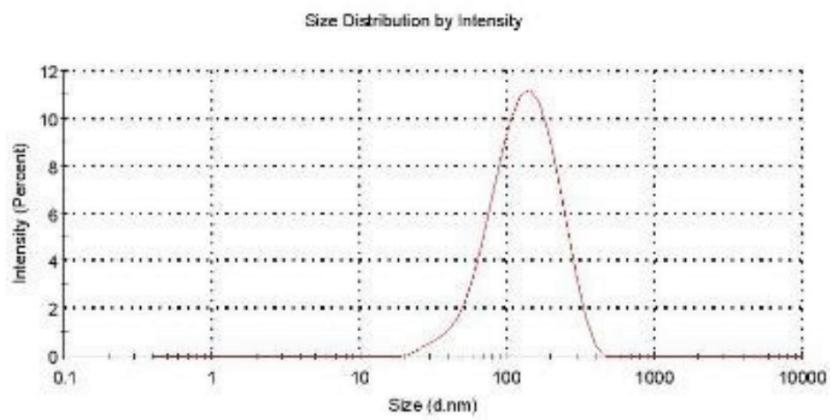

Figure 2: Size distribution pattern for globule size of the developed nanoemulsion.

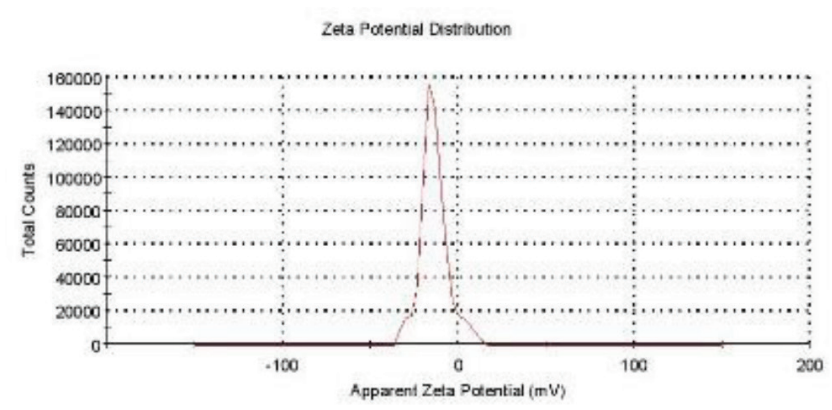

Figure 3: Zeta potential distribution of developed nanoemulsion.

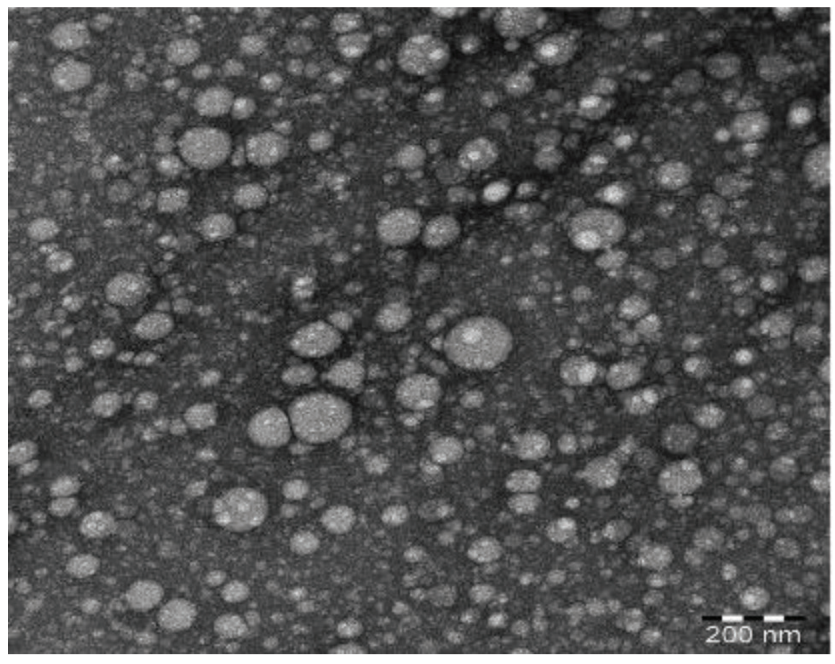

Figure 4: TEM image of the optimized formulation.

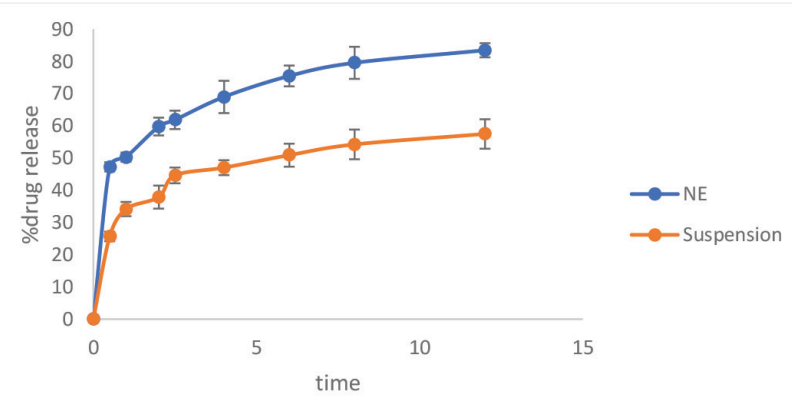

Figure 5: Percentage release of resveratrol from nanoemulsion and suspension.

\begin{tabular}{|c|c|c|c|c|}
\hline \multicolumn{5}{|c|}{ Table 1: Different formulation trials and results. } \\
\hline Formulation & $\begin{array}{c}\text { Tween 20: } \\
\text { PEG400 }\end{array}$ & Oil: Smix & $\begin{array}{c}\text { Droplet size } \\
\text { (nm) }\end{array}$ & PDI \\
\hline F1 & $1: 0.5$ & $1: 0.25$ & $321.5 \pm 21.74$ & $0.535 \pm 0.04$ \\
\hline F2 & $1: 0.5$ & $1: 0.5$ & $273.1 \pm 30.21$ & $0.619 \pm 0.02$ \\
\hline F3 & $1: 0.5$ & $1: 1$ & $210.3 \pm 19.3$ & $0.415 \pm 0.09$ \\
\hline F4 & $1: 1$ & $1: 0.25$ & $189.8 \pm 17.93$ & $0.311 \pm 0.07$ \\
\hline F5 & $1: 1$ & $1: 0.5$ & $113.6 \pm 18.21$ & $0.205 \pm 0.06$ \\
\hline F6 & $1: 1$ & $1: 1$ & $110.2 \pm 17.12$ & $0.237 \pm 0.02$ \\
\hline
\end{tabular}

tions F5 and F6 with minimum droplet size and PDI size were selected for further studies.

\section{Characterization of nanoemulsion \\ Droplet size and PDI}

The mean droplet size of developed resveratrol nanoemulsions were $113.6 \pm 18.21 \mathrm{~nm}$ for the formulation F5 and $110.2 \pm 17.12$ for the formulation F6 with a polydispersity index of $0.205 \pm 0.06$ for F5 and $0.237 \pm 0.02$ for F6. Figure 2 shows the size distribution pattern of formulation F5. The results were comparable to other published reports of similar systems. ${ }^{33}$

\section{Zeta potential}

The developed resveratrol nanoemulsions showed a zeta potential of $-15.12 \pm 1.028 \mathrm{mV}$ for formulation $\mathrm{F} 5$ (Figure 3) and $-14.34 \pm 2.011 \mathrm{mV}$ for formulation $\mathrm{F} 6$. Sufficient electrokinetic stability can be expected for 


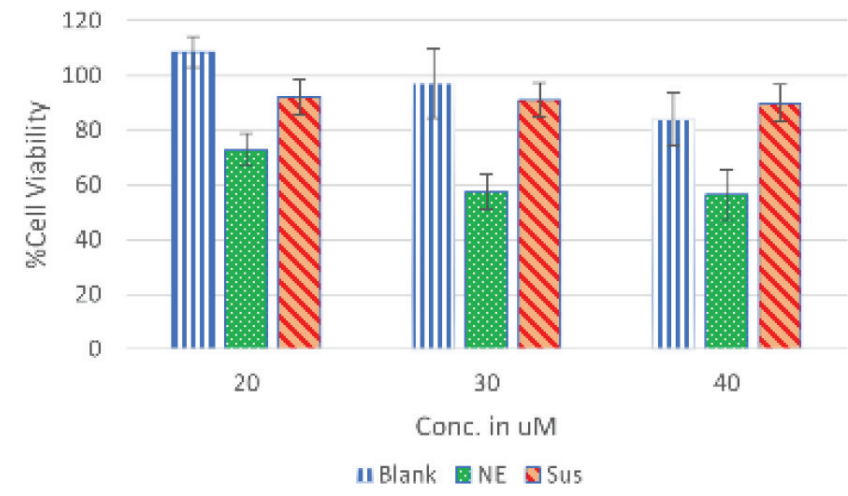

Figure 6: Activity of control, resveratrol nanoemulsion (NE), blank nanoemulsion (Blank) and efavirenz suspension (Suspension) at different concentration on the cell viability of HCT-166 cancer cells.

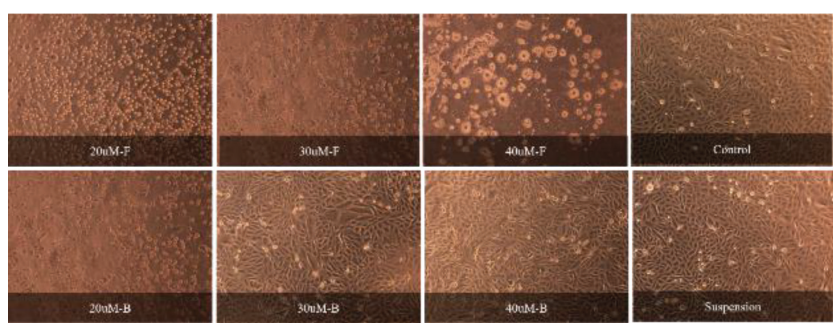

Figure 7: Cell morphology of treated HCT-166 cells.

a zetapotential value of above $15 \mathrm{mV}$ either negative or positive charge. ${ }^{30}$

\section{Transmission electron micrograph}

The TEM image revealed a uniform spherical morphology with globule size near $100 \mathrm{~nm}$ for the resveratrol nanoemulsion (Figure 4). This result was similar with the droplet size found by zeta sizer measurement. Also, the morphology of oil droplets was comparable to that of reported nanoemulsions formulated by phase inversion composition technique.

\section{Drug release}

The drug release from the developed resveratrol nanoemulsion was significantly greater as compared with resveratrol suspension (Figure 5). The release study was carried out in $0.1 \mathrm{~N} \mathrm{HCl}$ for the first two hr and then in $\mathrm{pH} 6.8$ Phosphate buffer till $8 \mathrm{hr}$. Nearly $60 \%$ of resveratrol released from both the formulation F5 and F6 in the first $2 \mathrm{~h}$, while only $37.87 \pm 3.56 \%$ from suspension. After $8 \mathrm{~h}$ nanoemulsion showed $83.43 \pm 2.2 \%$ release and suspension showed only $57.46 \pm 4.5 \%$ drug release. The very small size of droplets in nanoemulsion improved the resveratrol release by increasing the solubility is the reason for higher percentage of release as compared to suspension. ${ }^{34,35}$ Formulation F5 and F6 did not showed a significant difference in the percentage drug release, formulation F5 was selector for further studies since the percentage of surface tent is comparatively less as compared to formulation F6. Therefore, formulation F5 was selected as the optimized formulation and it contains $2 \mathrm{ml}$ of capryol 90, $0.5 \mathrm{ml}$ of Tween $20,0.5 \mathrm{ml}$ of PEG 400 and $3 \mathrm{ml}$ of water with $5 \mathrm{mg} / \mathrm{ml}$ of resveratrol.

\section{In vitro anticancer activity on HCT-166 cells}

To investigate the cytotoxic effect on HCT-116 cells, the cells were treated with an array of concentration $(20,30,40 \mu \mathrm{M})$ of resveratrol nanoemulsion, blank nanoemulsion, resveratrol suspension and control, and then the cell viability was measured after $48 \mathrm{hr}$. The in-vitro results showed that resveratrol nanoemulsion decreased the HCT-116 cells viability (Figure 6) in a dose-dependent manner.

From the results, it was observed that NE at 30 and $40 \mathrm{uM}$ are highly significant as compared to $20 \mathrm{uM}$ which is non-significant. The blank formulations did not showed any effect on cell viability at all the three selected concentrations. In our study it was observed that resveratrol seems to be selective for tumor cells evidenced by the very minimal toxicity against normal cells (Figure 7). Previous studies have reported that polyphenolic compounds possess anti-cancer effects metastasis and angiogenesis in various cancer cell. ${ }^{36,37}$ Based on previous studies, the cytotoxic effect of resveratrol was ascribed to different molecular mechanisms in favor of anticancer activity are the signaling pathways linked to extracellular growth factors and receptor tyrosine kinases; cell metabolism and formation of multiprotein complexes; genome instability and also cell proliferation. ${ }^{38,39}$ Other mechanisms include inflammation, immune surveillance and also apoptosis. It can also behave as a blocking agent by interrupting the transformation of procarcinogen to carcinogen, by inhibiting the monooxygenase cytochrome $\mathrm{P} 450$ isoenzyme. ${ }^{38} \mathrm{It}$ was evidenced that resveratrol can halt the cell cycle at $S$ phase in various cancer cells, such as breast, colon and pancreas. ${ }^{40-43}$ So the results prove that resveratrol nanoemulsion can effectively inhibit tumor cell growth in colon cancer cells in vitro. This study proved the effectiveness of resveratrol nanoemulsion in colon cancer cell lines for the first time.

\section{CONCLUSION}

In this study we formulated and characterized a resveratrol nanoemulsion formulation by a simple phase inversion technique. The developed nanoemulsion was proved to 
be very effective against in killing of HCT-166 colon cancer cells. Our study proved the dose dependent effect of resveratrol on killing of colon cancer cells, so we recommend adequate intake of resveratrol containing food or food supplements can prevent or manage colon cancer.

\section{CONFLICT OF INTEREST}

The author declares no conflict of interest.

\section{ABBREVIATIONS}

PEG: Polyethylene Glycol; HCT-166: Human colorectal cancer cell line; NE: Nanoemulsion.

\section{REFERENCES}

1. Rosman R, Saifullah B, Maniam S, Dorniani D, Hussein MZ, Fakurazi S. Improved anticancer effect of magnetite nanocomposite formulation of gallic acid (Fe3O4-PEG-GA) against lung, breast and colon cancer cells. Nanomaterials. 2018;8(2):83. doi: 10.3390/nano8020083.

2. Madhavi M, Madhavi $\mathrm{K}$, Jithan AV. Preparation and in vitro/in vivo characterization of curcumin microspheres intended to treat colon cancer. J Pharm Bioallied Sci. 2012;4(2):164-71. doi: 10.4103/0975-7406.94825, PMID 22557928.

3. Pisani P, Bray F, Parkin DM. Estimates of the world-wide prevalence of cancer for 25 sites in the adult population. Int J Cancer. 2002;97(1):72-81. doi: 10.1002/ijc.1571, PMID 11774246.

4. Siegel RL, Miller KD, Goding Sauer A, Fedewa SA, Butterly LF, Anderson JC, Cercek A, Smith RA, Jemal A. Colorectal cancer statistics, 2020. CA Cancer J Clin. 2020 May 1;70(3):145-64. doi: 10.3322/caac.21601, PMID 32133645.

5. Clément MV, Hirpara JL, Chawdhury SH, Pervaiz S. Chemopreventive agent resveratrol, a natural product derived from grapes, triggers CD95 signalingdependent apoptosis in human tumor cells. Blood. 1998;92(3):996-1002, PMID 9680369.

6. Bernhard D, Tinhofer I, Tonko M, Hübl H, Ausserlechner MJ, Greil R, Kofler R, Csordas A. Resveratrol causes arrest in the S-phase prior to Fas-independent apoptosis in $\mathrm{CEM}-\mathrm{C} 7 \mathrm{H} 2$ acute leukemia cells. Cell Death Differ. 2000;7(9):834-42. doi: 10.1038/sj.cdd.4400719, PMID 11042678.

7. Schneider Y, Duranton B, Gossé F, Schleiffer R, Seiler N, Raul F. Resveratrol inhibits intestinal tumorigenesis and modulates host-defense-related gene expression in an animal model of human familial adenomatous polyposis. Nutr Cancer. 2001 Jan 1;39(1):102-7. doi: 10.1207/S15327914nc391_14, PMID 11588890.

8. Schneider Y, Vincent F, Duranton B, Badolo L, Gossé F, Bergmann C, Seiler N, Raul F. Anti-proliferative effect of resveratrol, a natural component of grapes and wine, on human colonic cancer cells. Cancer Lett. 2000;158(1):85-91. doi: 10.1016/s0304-3835(00)00511-5, PMID 10940513.

9. Liang YC, Tsai SH, Chen L, Lin-Shiau SY, Lin JK. Resveratrol-induced G2 arrest through the inhibition of CDK7 and p34CDC2 kinases in colon carcinoma HT29 cells. Biochem Pharmacol. 2003;65(7):1053-60. doi: 10.1016/s0006-2952(03)00011-x, PMID 12663041.

10. Delmas D, Rébé C, Lacour S, Filomenko R, Athias A, Gambert P, CherkaouiMalki M, Jannin B, Dubrez-Daloz L, Latruffe N, Solary E. Resveratrol-induced apoptosis is associated with Fas redistribution in the rafts and the formation of a death-inducing signaling complex in colon cancer cells. J Biol Chem. 2003;278(42):41482-90. doi: 10.1074/jbc.M304896200, PMID 12902349.

11. Surh YJ, Hurh YJ, Kang JY, Lee E, Kong G, Lee SJ. Resveratrol, an antioxidant present in red wine, induces apoptosis in human promyelocytic leukemia (HL-60) cells. Cancer Lett. 1999;140(1-2):1-10. doi: 10.1016/s03043835(99)00039-7, PMID 10403535
12. Fulda S, Sieverts H, Friesen C, Herr I, Debatin KM. The CD95 (apo-1/fas) system mediates drug-induced apoptosis in neuroblastoma cells. Cancer Res. 1997;57(17):3823-9. PMID 9288794.

13. Santos AC, Pereira I, Pereira-Silva $M$, Ferreira $L$, Caldas $M$, Collado-González M, Magalhães M, Figueiras A, Ribeiro AJ, Veiga $F$. Nanotechnology-based formulations for resveratrol delivery: effects on resveratrol in vivo bioavailability and bioactivity. Colloids Surf B Biointerfaces. 2019;180:127-40. doi: 10.1016/j.colsurfb.2019.04.030, PMID 31035056.

14. Hao J, Gao Y, Zhao J, Zhang J, Li Q, Zhao Z, Liu J. Preparation and optimization of resveratrol nanosuspensions by antisolvent precipitation using Box-Behnken design. AAPS PharmSciTech. 2015;16(1):118-28. doi: 10.1208/ s12249-014-0211-y, PMID 25209687.

15. Singh G, Pai RS. Optimized PLGA nanoparticle platform for orally dosed trans-resveratrol with enhanced bioavailability potential. Expert Opin Drug Deliv. 2014;11(5):647-59. doi: 10.1517/17425247.2014.890588, PMID 24661109.

16. Siu FYK, Ye S, Lin H, Li S. Galactosylated PLGA nanoparticles for the oral delivery of resveratrol: enhanced bioavailability and in vitro anti-inflammatory activity. Int J Nanomedicine. 2018;13:4133-44. doi: 10.2147/IJN.S164235, PMID 30038494.

17. Chen J, Li F, Li Z, McClements DJ, Xiao H. Encapsulation of carotenoids in emulsion-based delivery systems: enhancement of $\beta$-carotene waterdispersibility and chemical stability. Food Hydrocoll. 2017;69:49-55. doi: 10.1016/j.foodhyd.2017.01.024.

18. Hao J, Zhao J, Zhang S, Tong T, Zhuang Q, Jin K, Chen W, Tang H. Fabrication of an ionic-sensitive in situ gel loaded with resveratrol nanosuspensions intended for direct nose-to-brain delivery. Colloids Surf B Biointerfaces. 2016;147:376-86. doi: 10.1016/j.colsurfb.2016.08.011, PMID 27566226.

19. Marques-Marinho FD, Vianna-Soares CD. Cellulose and its derivatives use in the pharmaceutical compounding practice. In: Cellulose-medical, pharmaceutical and electronic applications. IntechOpen; 2013.

20. Zhou M, Chen X. Preparation of transdermal formulations in resveratrol nanoparticles and pharmacokinetics study. In: International Conference on Smart City and Systems Engineering (ICSCSE). Vol. 2016. IEEE Publications; 2016. p. 632-5.

21. Jose S, Anju SS, Cinu TA, Aleykutty NA, Thomas S, Souto EB. In vivo pharmacokinetics and biodistribution of resveratrol-loaded solid lipid nanoparticles for brain delivery. Int J Pharm. 2014;474(1-2):6-13. doi: 10.1016/j.ijpharm.2014.08.003, PMID 25102112.

22. Penalva R, Esparza I, Larraneta E, González-Navarro CJ, Gamazo C, Irache JM. Zein-based nanoparticles improve the oral bioavailability of resveratrol and its anti-inflammatory effects in a mouse model of endotoxic shock. J Agric Food Chem. 2015;63(23):5603-11. doi: 10.1021/jf505694e, PMID 26027429.

23. Das S, Lin HS, Ho PC, Ng KY. The impact of aqueous solubility and dose on the pharmacokinetic profiles of resveratrol. Pharm Res. 2008;25(11):2593-600. doi: 10.1007/s11095-008-9677-1, PMID 18629618.

24. Kotta S, Khan AW, Ansari SH, Sharma RK, Ali J. Anti HIV nanoemulsion formulation: optimization and in vitro-in vivo evaluation. Int $\mathrm{J}$ Pharm. 2014;462(1-2):129-34. doi: 10.1016/j.jpharm.2013.12.038, PMID 24374067.

25. Bali V, Ali M, Ali J. Study of surfactant combinations and development of a novel nanoemulsion for minimising variations in bioavailability of ezetimibe. Colloids Surf B Biointerfaces. 2010;76(2):410-20. doi: 10.1016/j. colsurfb.2009.11.021, PMID 20042320.

26. Kotta S, Khan AW, Pramod K, Ansari SH, Sharma RK, Ali J. Exploring oral nanoemulsions for bioavailability enhancement of poorly watersoluble drugs. Expert Opin Drug Deliv. 2012;9(5):585-98. doi: 10.1517/17425247.2012.668523, PMID 22512597.

27. Guttoff M, Saberi AH, McClements DJ. Formation of vitamin D nanoemulsionbased delivery systems by spontaneous emulsification: factors affecting particle size and stability. Food Chem. 2015;171:117-22. doi: 10.1016/j. foodchem.2014.08.087, PMID 25308650.

28. Khan AW, Kotta S, Ansari SH, Sharma RK, Ali J. Potentials and challenges in self-nanoemulsifying drug delivery systems. Expert Opin Drug Deliv. 2012;9(10):1305-17. doi: 10.1517/17425247.2012.719870, PMID 22954323.

29. Kotta S, Khan AW, Ansari SH, Sharma RK, Ali J. Formulation of nanoemulsion: A comparison between phase inversion composition method and highpressure homogenization method. Drug Deliv. 2015;22(4):455-66. doi: 10.3109/10717544.2013.866992, PMID 24329559 
30. Kotta S, Mubarak Aldawsari H, Badr-Eldin SM, Alhakamy NA, Md S. Coconut Oil-based resveratrol nanoemulsion: optimization using response surface methodology, Stability assessment and pharmacokinetic Evaluation. Food Chem. 2021;357:129721. doi: 10.1016/j.foodchem.2021.129721.

31. Wang Y, Liu Y, Tang T, Luo Y, Stevens MFG, Cheng X, Yang Y, Shi D, Zhang J, Bradshaw TD. The antitumour activity of 2-(4-amino-3-methylphenyl)-5fluorobenzothiazole in human gastric cancer models is mediated by AhR signalling. J Cell Mol Med. 2020;24(2):1750-9. doi: 10.1111/jcmm.14869, PMID 31876059.

32. Leong CO, Suggitt M, Swaine DJ, Bibby MC, Stevens MFG, Bradshaw TD. In vitro, in vivo, and in silico analyses of the antitumor activity of 2-(4-amino3-methylphenyl)-5-fluorobenzothiazoles. Mol Cancer Ther. 2004 Dec;3(12):1565-75. PMID 15634650.

33. Kotta S, Khan AW, Ansari SH, Sharma RK, Ali J. Formulation of nanoemulsion: a comparison between phase inversion composition method and highpressure homogenization method. Drug Deliv. 2015 May;22(4):455-66. doi: 10.3109/10717544.2013.866992, PMID 24329559.

34. Jaiswal M, Dudhe R, Sharma PK. Nanoemulsion: an advanced mode of drug delivery system. 3 Biotech. 2015 Apr;5(2):123-7. doi: 10.1007/s13205-0140214-0, PMID 28324579

35. Davidov-Pardo G, McClements DJ. Nutraceutical delivery systems: resveratrol encapsulation in grape seed oil nanoemulsions formed by spontaneous emulsification. Food Chem. 2015;167:205-12. doi: 10.1016/j. foodchem.2014.06.082, PMID 25148980.

36. Jang M, Cai L, Udeani GO, Slowing KV, Thomas CF, Beecher CWW, Fong $\mathrm{HH}$, Farnsworth NR, Kinghorn AD, Mehta RG, Moon RC, Pezzuto JM. Cancer chemopreventive activity of resveratrol, a natural product derived from grapes. Science. 1997;275(5297):218-20. doi: 10.1126/ science.275.5297.218, PMID 8985016.

37. Zhou JH, Cheng HY, Yu ZQ, He DW, Pan Z, Yang DT. Resveratrol induces apoptosis in pancreatic cancer cells. Chin Med J (Engl). 2011;124(11):1695-9. PMID 21740780.

38. Varoni EM, Lo Faro AF, Sharifi-Rad J, Iriti M. Anticancer molecular mechanisms of resveratrol. Front Nutr. 2016;3:8. doi: 10.3389/fnut.2016.00008, PMID 27148534.

39. Aljabali AA A, A Bakshi H, L Hakkim F, Haggag YA, M Al-Batanyeh $\mathrm{K}$, $S$ Al Zoubi M, et al. Albumin nano-encapsulation of piceatannol enhances its anticancer potential in colon cancer via downregulation of nuclear p65 and HIF-1a. Cancers (Basel). 2020;12(1):113.

40. Miki H, Uehara N, Kimura A, Sasaki T, Yuri T, Yoshizawa K, Tsubura A. Resveratrol induces apoptosis via ROS-triggered autophagy in human colon cancer cells. Int J Oncol. 2012;40(4):1020-8. doi: 10.3892/ijo.2012.1325, PMID 22218562.

41. Aziz MH, Kumar RAJ, Ahmad N. Cancer chemoprevention by resveratrol: in vitro and in vivo studies and the underlying mechanisms (review). Int J Oncol. 2003;23(1):17-28. doi: 10.3892/ijo.23.1.17, PMID 12792772.

42. Shi Y, Yang S, Troup S, Lu X, Callaghan S, Park DS, Xing Y, Yang X. Resveratrol induces apoptosis in breast cancer cells by E2F1-mediated up-regulation of ASPP1. Oncol Rep. 2011;25(6):1713-9. doi: 10.3892/ or.2011.1248, PMID 21479363.

43. Das D, Preet R, Mohapatra P, Satapathy SR, Kundu CN. 1,3-Bis(2chloroethyl)-1-nitrosourea enhances the inhibitory effect of resveratrol on 5-fluorouracil sensitive/resistant colon cancer cells. World J Gastroenterol. 2013;19(42):7374-88. doi: 10.3748/wjg.v19.i42.7374, PMID 24259968.

\section{PICTORIAL ABSTRACT}

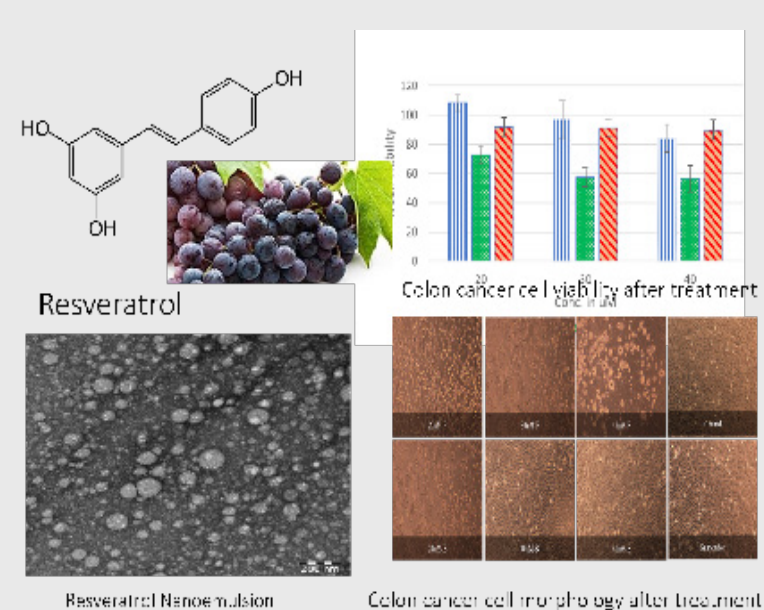

\section{SUMMARY}

- Resveratrol has been proved to be beneficial in the management of Colorectal cancer.

- The poor aqueous solubility of resveratrol is improved by nanoemulsion formulation.

- The developed nanoemulsion was proved to be very effective against in killing of HCT-166 colon cancer cells.

- So adequate intake of resveratrol can prevent or manage colon cancer.

\section{About Authors}

Dr Sabna Kotta is working as an Assistant Professor in the Department of Pharmaceutics in King Abdulaziz University, Saudi Arabia. Her area of research interest is Drug delivery, Bioavailability improvement, Nanotechnology platforms for drug delivery, Carbon dots etc.

Cite this article: Kotta S. Formulation of Resveratrol Nanoemulsion by Phase Inversion Technique and Evaluation of Anti-Cancer Activity on Human Colon Cancer Cell Lines. Indian J of Pharmaceutical Education and Research. $2021 ; 55(3 s): s 623-s 629$. 